\title{
A proportional study of contemporary Bio safety rules and Islamic traditions regarding innate privileges of animals
}

\author{
Dr. Inam Ullah Wattu
}

Assistant Professor, Department of Social \& Allied Sciences Cholistan University of veterinary \& Animal Sciences, Bahawalpur.

Email: inamullah@cuvas.edu.pk

\author{
Mr. Yasir Farooq \\ Lecturer, Department of Islamic Studies, \\ Govt. MD College, Faisalabad. \\ Email: yasirfarooq797@gmail.com \\ DOI: 10.33195/journal.v4i01.257
}

\begin{abstract}
:
Biosafety is the anticipation of significant forfeiture of biotic reliability, concentrating equally on bionetwork and hominid fitness. Use of animals and plants for experimental purposes is a controversial issue in recent days. Advanced states have constituted its biosafety and bioethical rules for security and survival of animals. Which prohibited unethical use of animals and ill treatment. All academic and research institutions are bound to constitute an ethical review committee which is assigned to review and supervise research activities conducted in institute. Contemporary Bioethical rules are assumed to secure the basic rights of animals. Islam has also set ethical principles for survival and security of animals and assure their innate privileges. Animals are an inordinate sanctification of Allah Almighty, many of our daily necessities are associated with them, and there is no denying the importance of animals in human life. As per Islamic education feeding and proper treatment and shelter are fundamental rights of animals and owner of animals is bound to provide these facilities. Moreover, cursing, beating, teasing and unnecessarily slaughter of animals is disliked. Major difference between contemporary bioethical rules regarding animal rights and Islamic teachings is use of animal for food purposes.
\end{abstract}

Keywords: Bionetwork, hominid, biosafety, bioethical, ethical principles, slaughter.

\section{Introduction/Biosafety}

Biosafety is the anticipation of significant forfeiture of biotic reliability, concentrating equally on bionetwork and hominid fitness ${ }^{1}$. Legislation regarding use of animals in laboratories for all kind of animals in United 
States under Animal welfare Act and the Guide ${ }^{2}$ any experiment can be performed after scientific justification and researcher are advised to contact with veterinarian of institution and IACUC ${ }^{3}$.

Animal rights is a study in which almost all animals are addressed to the right of their existence and all other basic necessities are considered as of human beings. Following are basic rights for animals: use of animals for experiments is prohibited, killing and breeding of animals for medicine, clothes and food is also not permitted, animals cannot be used for hard labor, selective breeding of animals is also illegal other than their benefit, hunting of animals and their use for entertainment or zoos are also not allowed.

\section{Universal Declaration on Animal Welfare (UDAW):}

Universal Declaration on Animal Welfare (UDAW) is designed an international deed to consider that animals are perceptive, to avert brutality and decrease distress, and to encourage principles on the safety of animals such as farm animals, companion animals, animals in scientific research, draught animals, wildlife and animals in recreation ${ }^{4}$.

\section{The declaration Proposed:}

- Acknowledgement that animals are breathing, responsive existences and consequently warrant outstanding contemplation and veneration

- Acknowledgment that animal prosperity comprises animal fitness and comprises equally the corporeal and psychosomatic state of the animal and that upright does in animal safety can have foremost welfares for hominids and the environment

- Acknowledgment that on this planet human beings are in co-existing form with all other species like animals and plants and all species including human and animals deserve equal rights.

- Acknowledgment of the worth of continuous struggle of $\mathrm{OIE}^{5}$ for introducing international principles for the welfare of animals adopted by member states for the implementation of standard principles and essential measures for its effectiveness.

- Recognition of the legal protection system adopted by different states both for domestic and wild.

- Wakefulness about five freedoms and 3Rs.

- Acknowledgement that the terms/conditions or rules of this declaration do not disturb the domestic rights of any member state.

Five freedoms

"Freedom from hunger, thirst and malnutrition; freedom from fear and distress; freedom from physical and thermal discomfort; freedom from pain, injury and disease; and freedom to express normal patterns of behavior $6 "$ 


\section{The Three RS}

The Three RS (3RS) are supervisory moralities for additional proper procedure of wildlife in experiments. Firstly presented in 1959 by W.M.S. Russell and R.L. Burch ${ }^{7}$. Replacement, Reduction and Refinement ${ }^{8}$.

"Reduction in numbers of animals,
refinement of experimental methods and
replacement of animals with non-animal
techniques"

The 3Rs consume a wider cosmos than just inspiring substitutes to intuitive experiments with struggle to improve welfare of and scientific quality where use of animal for testing is unavoidable. Now 3RS are being used in number of labs at world level and have also become a legislated part of many organizations ${ }^{10}$.

It is also reported that despite of adopting 3RS at large level still in many countries like Australia, South Korea, Germany and Israel use of animal for testing is increasing every year ${ }^{11}$.

\section{The doctrines of the assertion are:}

1. All member states are advised to take necessary measure for prevention of brutality to wild and to decrease the suffering of animals and this should be a common objective.

2. Animal welfare policies and legislations shall be recognized by improved national and international measures. All member states are bound to treat animals in sustainable manner as per directions of the assertion.

3. State is responsible to take serious actions for prevention of cruelty to animals and to decrease their distress.

4. Suitable strategies, legislature and ethics for the safety of wildlife will be auxiliary urbanized and expounded.

\section{Islam and innate privileges of animals}

Animals are an inordinate sanctification of Allah Almighty, many of our daily necessities are associated with them, and there is no denying the importance of animals in human life. Islam is a comprehensive and perfect religion, even Islam has defined the rights of animals The Creator of the universe Himself has mentioned their importance in His Word:

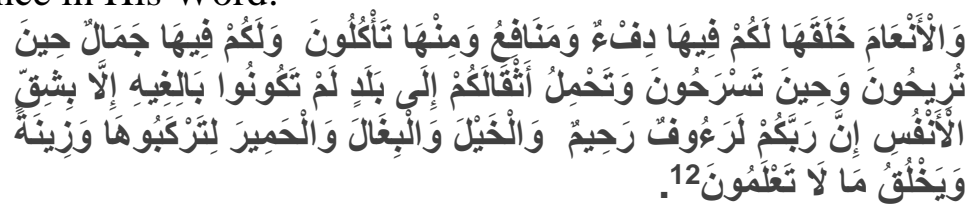

In addition, statements about the importance and rights of animals are found in about 200 verses of the Holy Qur'an. And about five Surah's are named after these animals: Surah Al-Baqarah (Cow), Surah An-Nahl (The Bee), 
Surah An-Naml (The Ant), Surah Ankabut (The Spider), Surah Al-Fil (The Elephant) and Surah An-Naam (The Cattle). And there are about 35 animals mentioned in the Qur'an from which their importance can be gauged. Their importance has also been highlighted in the ahadiths.

\section{The virtue of feeding animals:}

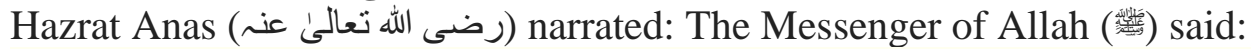
"ما من مسلم يغرس غرسا او يذرع زرعا، فياكل من انسان او طير او بهيمة الا كاتت لـ

Whoever a Muslim cultivates or plants, then if a person or a bird or an animal eats from it, it will be a charity for him.

From this the reward of feeding the living thing is known that a servant sows a field and eats a living thing from that field and the owner of that field does not even know that the cattle, birds, etc. which are eating from his field The reward of charity is being written in deeds. Now, if someone keeps a living animal and then gives it fodder, etc., what will be the reward for it? In the same way, harming an animal, starving it, is the worst sin. In another tradition of Sahih Muslim.

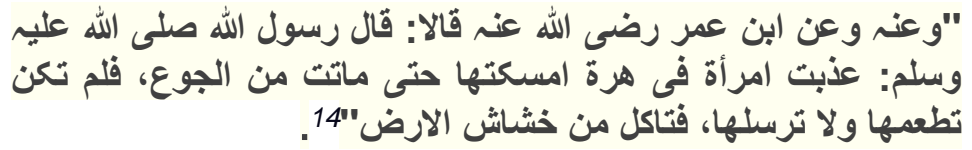

"The Prophet (践) said, "A woman entered the (Hell) Fire because of a cat which she had tied, neither giving it food nor setting it free to eat from the vermin of the earth."

What a solemn warning that this woman was being tormented in hell for hurting a cat. In another narration, the Holy Prophet ( said: I saw a woman in Hell, who was in the case of a cat, the torment was such that the cat would bite her when the woman came forward and when she lowered her head, and cat would scratch her head.

\section{Prohibition of cursing animals:}

Islam also forbids cursing animals as it is narrated:

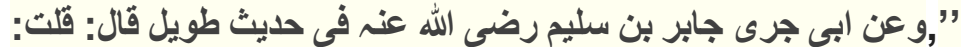

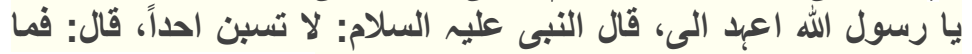

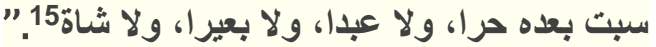

There is a long hadith narrated from Abu Jari Jabir bin Saleem (رضى الله تعالئ عند) that I entreated to the Prophet of Allah (縉) to

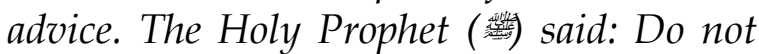
speak ill of anyone. He said: I have not spoken evil of anyone after this, neither to the free 
man, nor to the slave, nor to the camel nor to

the goat.

Similarly, another narration states:

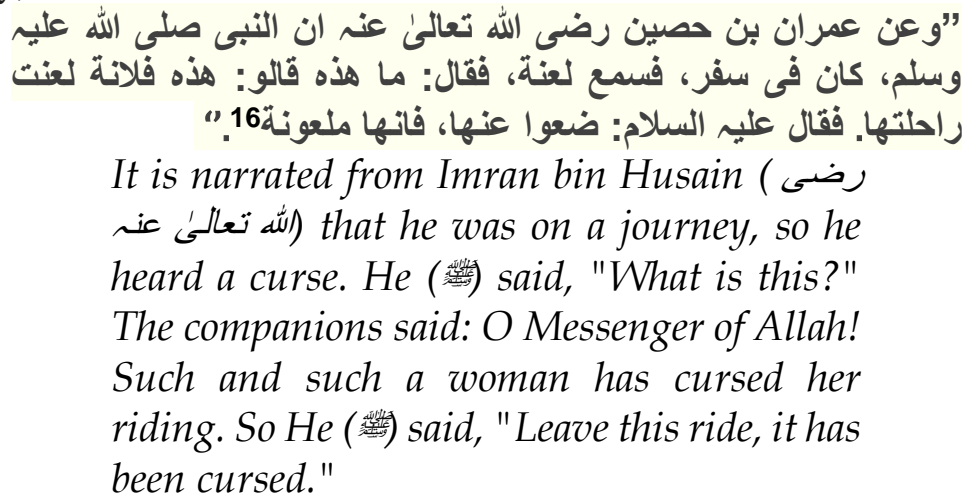

From these hadiths it is known that cursing animals, cursing them, as is the custom of some people, is a very heinous act in the eyes of Shariah.

\section{Warning to harm animals unnecessarily:}

There are many hadiths regarding the harm of animals, in which there is a warning to harm the animals, and the Prophet (踩) expressed his anger towards a person who harms the animals unnecessarily, and on certain

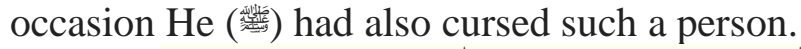

$$
\begin{aligned}
& \text { عن ابن عمر رضى الله عن ان النبى صلى الله عليم وسلم لعن من }
\end{aligned}
$$

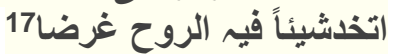

Some people tie up animals and shoot them with arrows etc. just for the purpose of shooting practice or for occupation. The Prophet (torbade this and cursed such a person. Similarly, he said:

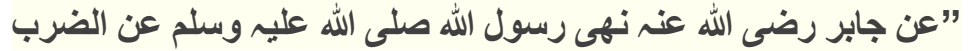

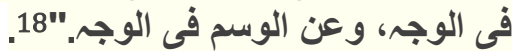

It is narrated by Jabir (رضى الله تعالئ عن الوجر) that the Prophet (worbade hitting on the face and burning on the face.

That's why, He (also forbade hitting the face of an animal and it is narrated in a hadith that a donkey passed in front of the Holy Prophet (繁) and had a mark on his face. He (waid: May Allah curse the person who has tarnished his face., Which is a highly undesirable act and cruelty to dumb animals.

$$
\text { وعن ابن عباس رضى الله عنهما قال نهى رسول الله صلى الله عليم وسلم }
$$




\section{Hazrat Ibn Abbas (رضى اله تعالئ عن) says that the Prophet (forbade fighting among animals.}

Fighting chickens and bats and fighting rams as well as fighting another animal are all included in the same prohibition and it is all harām. Keeping animals hungry and not taking care of their food and drink is also cruelty, which is a cause of torment.

It is narrated by 'yaala ibn Marah al-Thaqafi (رضى الله تعالى عن) that he said: I saw three strange incidents from the Messenger of Allah (䄰). One of them was that we were travelling with the Prophet of Allah (when suddenly we saw a camel which was used for irrigation, when the camel saw Him (4), it started bubbling and bent the front part of its neck, He (stood beside the camel and said that where the owner of camel is. The owner of camel came. He (said, "Sell it to me." He said, "Not the Messenger of Allah, but we give it to you as gift, and it belongs to a family which has no other means of subsistence." He (waid that the camel has complained of taking more work and giving less food.

Nowadays, there is a lot of negligence in this matter. It has become a common practice to take excessive work from animals without taking care of their food. Plowmen, donkey drivers, etc., read these teachings carefully. And review their practices. The oxen and donkeys should be used without any hardship or beating. It is recommended that these animals should not be overburdened and should not be hit on the head and mouth.

\section{Animal riding rights:}

Allah Almighty has subjugated large animals for man. Man derives various benefits from these animals. One of them is the benefit of riding on them. The Shariah has also laid down its rules for this.

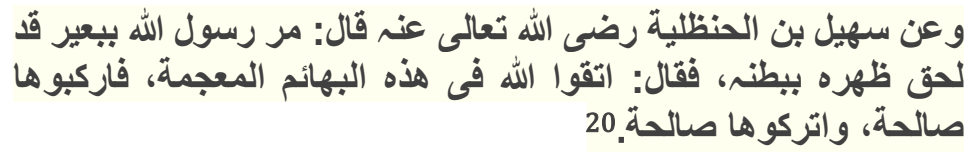

Hazrat Sahl Ibn Hanzaliyah ( رضى الله تعالى (ع) says that when the Prophet (wassed by a camel, he saw that his back was hit by his stomach due to extreme hunger and thirst and excessive riding. He said: Be careful of (your duty to) Allah concerning these dumb cattle, and ride on them while they are strong and able to ride, and leave them in a good condition so that they do not get tired ${ }^{21}$.

It is also narrated that when you travel on a dry plain land, travel quickly there because the animal will suffer in a leisurely journey, because there 
will be no fodder for it on dry land and when it is green land, then give the animal its due mean leave them for a little to eat and in the same narration it is narrated that:

\section{Do not make the back of your riding a pulpit.}

That is, if there is a place to stop during the journey or if you have to stop for the purpose of talking to someone, it is commanded to get off the back of the animal, because it will hurt them in this way. It is narrated on the authority of Anas ibn Malik that he used to say that when we encamped on a destination, we would not offer prayers until we freed the animal form burden.

\section{Animal slaughter rights:}

Allaah says in the Qur'aan:

\section{We have made lawful for you the pour things}

Allah has permitted the flesh of many animals for man. Man can slaughter and eat these animals if necessary, but Allah has also given some commands for this.

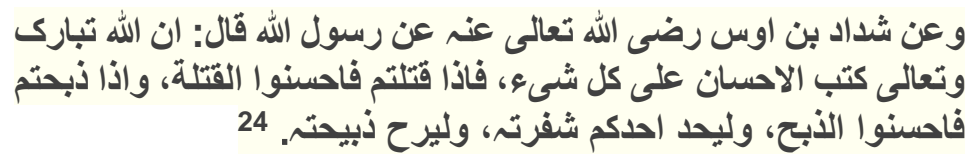

Hazrat Shaddad bin Muslim says that the Holy Prophet (allah Almighty has made it necessary to do good with everything, so when you kill (a criminal) then kill in a good way and when you (someone) kill (Slaughter the animal) then slaughter it in a good way and this good way also includes that whoever among you is going to do this work should sharpen his knife and give relief to the slaughter. And the Shari'ah forbids slaughtering an animal in front of another animal and also dislikes sharpening a knife in front of an animal. The Shari'ah forbids slaughtering an animal unnecessarily, ie eating its meat when it is not intended.

It is narrated by Hazrat Abdullah bin Amr (رضى الله تعالى عن) that the Holy Prophet (jaid that if anyone kills a bird or an animal bigger than it against its right, then Allah Almighty will ask about its killing. The companions said: O Messenger of Allah ( what is its right? He ( slaughter it for food and not cut off its head and throw it away.

It means that we should not kill any animal unnecessarily and we should slaughter animal with standard slaughter rules for meat purposes only.

Fighting between animals and teasing is prohibited:

The Prophet (not only forbade the abuse and domestic violence of domestic animals; He also forbade teasing non-pets: 
It is narrated by ibn 'Abbas that the Prophet

(* forbade animals to fight among themselves. ${ }^{25}$

Hazrat Abdul Rahman bin Abdullah (رضى الله تعالى عن) narrates from his father that he said that once we were traveling with the Holy Prophet (s) when on one occasion the Holy Prophet (歯) went for some personal matters than we saw a bird with two children. We caught the two children. Then the bird came and started protesting against the arrest of its children. When the Prophet (whe came and saw the bird so desperate, he said, "Who has seized her children and made her anxious?" Give back her children ${ }^{26}$.

It is narrated from Ibn Umar (رضى الله تعالى عنى) that he passed by some young men of Quraysh who were targeting a bird or a hen. When Ibn Umar (رضى ) (الله تعالى عن saw them, they dispersed and He said: The Prophet (繁) cursed the one who binds a living thing and strikes it $^{27}$.

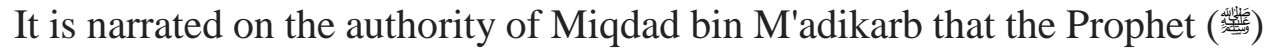
forbade slapping the faces of cattle.

\section{Kindness in killing predatory animals:}

The Prophet (the killing of predators, such as snakes, scorpions, etc. But even in killing them, the Prophet commanded kindness and goodness. Allah has made it obligatory to do well in all things. So when you kill an animal, kill it in a good way, and when you slaughter it, slaughter it in a good way ${ }^{28}$.

Once on an occasion He (4. lit it?" We said we burned. The Prophet (- said: It is not permitted for anyone to harm others with fire except the creator of the fire ${ }^{29}$.

The Prophet (to kill the lizard but with gentleness and kindness. So it is order to kill it in first blow. He said that killing it in multiple blows would bring less reward. It is narrated from Hazrat Abu Hurayrah (رضى الله تعالئ عن) that the Prophet (籍) said: Whoever kills a lizard in the first blow, there are so many virtues for him, And whoever strikes him with a second blow, there are virtues for him; But less than the firsttimer, and if he hits the third time, there are virtues for him. But less than the second blow ${ }^{30}$.

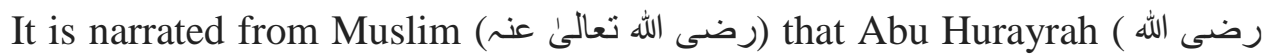
(تعالى عن said: The Prophet (ت said: Whoever kills a chameleon in a single blow, a hundred good deeds will be written for him, less in the second war and less than that in the third ${ }^{31}$.

\section{Do not overload animals:}

It is not permissible to impose a burden on an animal beyond its strength and power. The Prophet (strictly forbade it. He will have to give an account on the Day of Resurrection. It is narrated by Abu Darda ( رضى الله 
that he said to his camel: O camel, do not quarrel with your Lord over me, I have not burdened you beyond your strength.

One day the Prophet entered in the garden of an Ansaari. Suddenly a camel came and began to follow in his footsteps. At that time there were tears in his eyes. He (urned his hand on the back of his head, which calmed him down. Then the Prophet (waid, 'Who is the owner of this camel?' So he came running. The Prophet said to him: "Allah has given it to you. Do not fear Allah. He is complaining to me that you keep him hungry. You work harder and harder. ${ }^{32}$

Hazrat Abu Hurayrah (رضى الله تعالى عن) said that the Prophet (رش man was chasing an ox with a load. The ox looked at the man and said: I have not been created for this purpose. Rather, I was created for farming. People said Subhan Allah in astonishment and panic and said does the bull also speak? The Messenger of Allah (waid: I believe in that, and so do Abu Bakr and Umar. ${ }^{33}$

\section{Conclusion}

Animal rights is a study in which almost all animals are addressed to the right of their existence and all other basic necessities are considered as of human beings. Following are basic rights for animals: use of animals for experiments is prohibited, killing and breeding of animals for medicine, clothes and food is also not permitted, animals cannot be used for hard labor, selective breeding of animals is also illegal other than their benefit, hunting of animals and their use for entertainment or zoos are also not allowed. Now 3RS are being used in number of labs at world level and have also become a legislated part of many organizations. It is also reported that despite of adopting $3 \mathrm{RS}$ at large level still in many countries like Australia, South Korea, Germany and Israel use of animal for testing is increasing every year. Animals are an inordinate sanctification of Allah Almighty, many of our daily necessities are associated with them, and there is no denying the importance of animals in human life. Islam is a comprehensive and perfect religion, even Islam has defined the rights of animals.

\section{Notes and References}

1. Biosafety and the environment: An introduction to the Cartagena Protocol on Biosafety (PDF). GE.03-01836/E. United Nations Environment Programme. p. 8.

${ }^{2}$. Guide for the Care and Use of Laboratory Animals (the Guide), published by the National Academy of Sciences

${ }^{3}$. Institutional Animal Care and Use Committee

4. Universal Declaration on Animal Welfare Archived 2009-07-05 at the Wayback

Machine (This is the 2005 draft version. See reference to a newer 2011 version in the history section. Note that as at June 2012 this is still a draft proposal, not an international treaty in force.)

5. World Organization for Animal Health 
${ }^{6}$. The Five Freedoms Archived October 5, 2013, at the Way back Machine as defined on the Farm Animal Welfare Council website, accessed 5 August 2008

7. Russell, W. M. S. (William Moy Stratton); Health, JH Bloomberg School of Public (1992). The principles of humane experimental technique (Special ed.). South Mimms, Potters Bar, Herts, England: Universities Federation for Animal

Welfare. ISBN 0900767782. OCLC 27347928.

${ }^{8}$. Badyal D., Desai C. (2014). "Animal use in pharmacology education and research: The changing scenario". Indian Journal of Pharmacology. 46 (3): 257-

65. doi:10.4103/0253-7613.132153. PMC 4071700. PMID 24987170

${ }^{9}$. For definition, see 7.1 of Chapter 7: The Three R's: Alternatives to animal experiments by the Select Committee on Animals In Scientific Procedures, accessed 5 August 2008

10. Liguori, G.; et al. (2017). "Ethical Issues in the Use of Animal Models for Tissue Engineering: Reflections on Legal Aspects, Moral Theory, 3Rs Strategies, and HarmBenefit Analysis" (PDF). Tissue Engineering Part C: Methods. 23 (12): 85062. doi:10.1089/ten.TEC.2017.0189. PMID 28756735.

11. Even, Dan (29 May 2013). "Number of animal experiments up for first time since 2008". Haaretz. Retrieved 7 July 2015. 12 12-1آقرآ- النحل:4-4

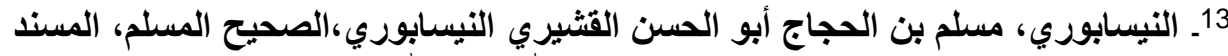

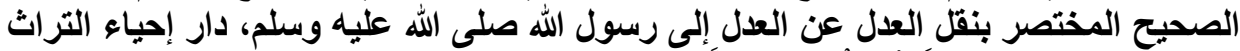

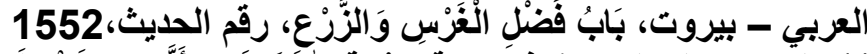

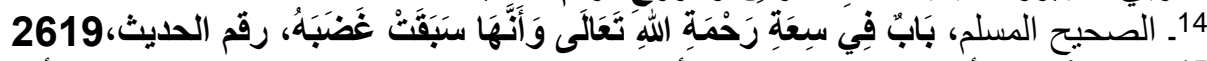

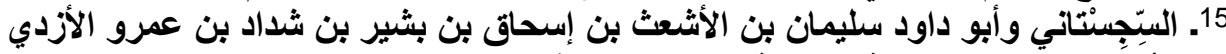

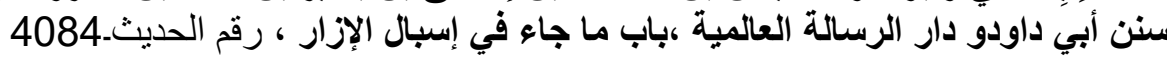

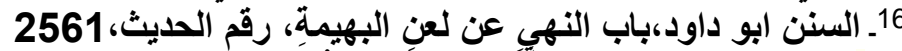

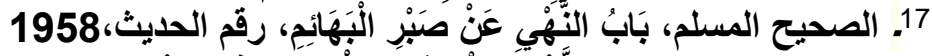

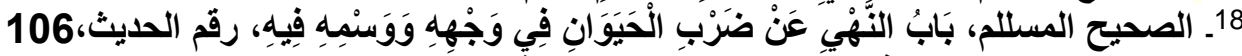

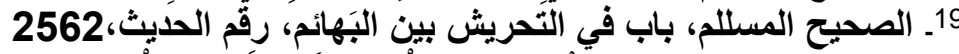

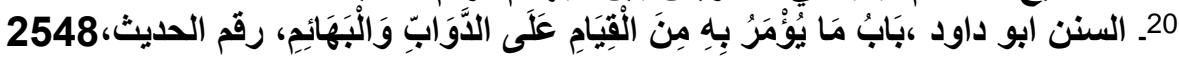

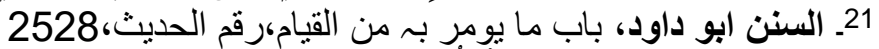

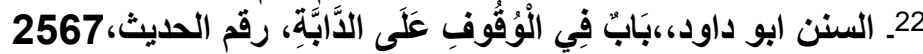

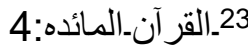

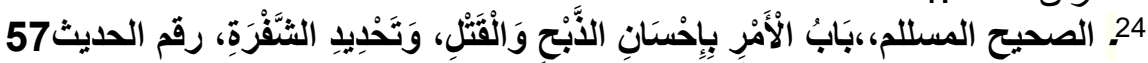

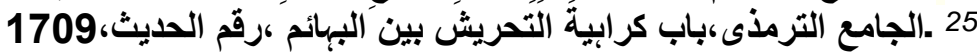

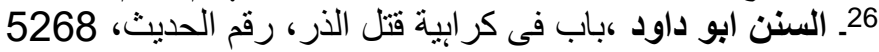

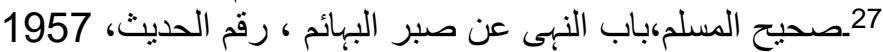

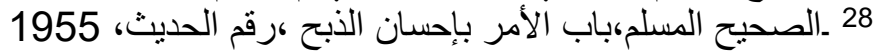

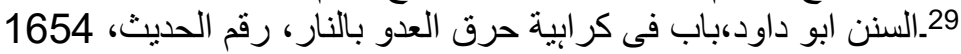
30 الصحيح المسلم،باب استحباب قتل الوزئ الوزع، رقم الحديث، 2238

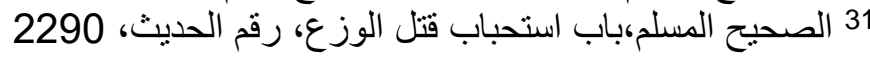

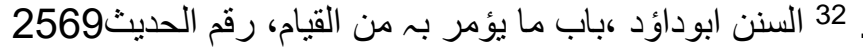
33_الصحيح المسلم، باب فضائل أبى بكر، برقم الحديث، رفي 2388 